\section{NOVA TELLVS}

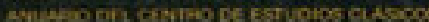

Nova Tellus

ISSN: 0185-3058

novatelu@servidor.unam.mx

Centro de Estudios Clásicos

México

García Pérez, David

Retórica y política en torno a Alcibíades

Nova Tellus, vol. 27, núm. 1, 2009, pp. 41-58

Centro de Estudios Clásicos

Distrito Federal, México

Disponible en: http://www.redalyc.org/articulo.oa?id=59115499002

- Cómo citar el artículo

- Número completo

- Más información del artículo

- Página de la revista en redalyc.org

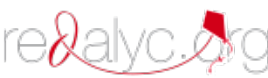

Sistema de Información Científica

Red de Revistas Científicas de América Latina, el Caribe, España y Portugal

Proyecto académico sin fines de lucro, desarrollado bajo la iniciativa de acceso abierto 


\title{
Retórica y política en torno a Alcibíades
}

\author{
David GARCÍA PÉREZ \\ Universidad Nacional Autónoma de México \\ prometeo9@att.net.mx
}

RESUMEN: En este artículo se analiza una serie de argumentos retóricos basados en

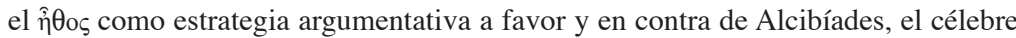
político y estratego ateniense, en el marco de la política desarrollada por las heterías atenienses entre los siglos v y IV a. C. El objetivo es explorar cómo se define el perfil político, específicamente el de Alcibíades, desde el ámbito del discurso en el que las fronteras de los géneros judicial y deliberativo se desvanecen, lo mismo que los espacios de lo público y lo privado.

$$
* * *
$$

ABSTRACT: In this paper a series of rhetorical arguments devised within the political frame of the Athenian hetaireiai of the $\mathrm{V}$ and IV centuries b. C. is analyzed, which are based on the ethos as an argumentative strategy for and against Alcibiades, the celebrated Athenian politician and strategist. The aim of this study is to explore how a political profile is defined - in reference more specifically to Alcibiades-, looking at the matter from the boundary of speech where the frontiers between judicial and deliberative speech genres vanish away, while the public and the private spheres coalesce.

PALABRAS Clave: Alcibíades, Andócides, î̀日os, hetería, Isócrates, Lisias, política, retórica.

KeYwords: Alcibiades, Andocides, 令os, hetaireia, Isocrates, Lysias, politics, rhetoric.

RECEPCIÓN: 27 de junio de 2008.

ACEPTACIÓN: 27 de mayo de 2009. 


\title{
Retórica y política en torno a Alcibíades*
}

\author{
David GARCÍA PÉREZ
}

En la lucha por obtener el poder político, los medios de que se dispone, resultan ser de lo más variado, tal como enseña la práctica de los estadistas, pero todos esos instrumentos tienen su mejor exponente en la palabra que, como sostuvo Gorgias, ${ }^{1}$ es capaz de hechizar a los oyentes, de cautivarlos y conducirlos hacia un punto específico, a pesar de que no se diga necesariamente la verdad. Para los políticos de la democracia ateniense (siglos v y IV) la persuasión a través de la palabra fue la herramienta principal para desarrollar sus planes políticos y militares. ${ }^{2}$ En este sentido, la controvertida figura de Alcibíades ocupa un lugar destacado en la historia ateniense en torno a la segunda fase de la Guerra del Peloponeso y la expedición a Sicilia (415); su influencia política en asuntos cruciales de la vida de Atenas crearon condiciones para concretar alianzas a su favor y en su contra. Fue precisamente la notoria actividad política y militar de Alcibíades lo que lo hizo objeto de una retórica deliberativa y judicial que descuella por los argumentos edificados en torno a su persona. La construcción retórica de su ì $\theta_{0}$ fue motivo de una serie de discursos que resultan un ejemplo práctico de la logografía basada en el carácter del individuo.

\footnotetext{
* Este trabajo forma parte de la investigación desarrollada en el proyecto "El dominio retórico y sus modelos", PAPIIT IN 403708, UNAM.

${ }^{1}$ Gorg., Encomio de Helena, B 11, 14. Cf. J. de Romilly, "Gorgias et le pouvoir de la poésie", JHS, 93, 1973, pp. 155-162

${ }^{2}$ Antonio López Eire, "La oratoria”, en Juan Antonio López Férez, Historia de la Literatura Griega, Madrid, Cátedra, 2000, p. 794.
}

NOVA TELLVS, 27•1, 2009 
Aristóteles expone el sentido del término $\hat{\eta} \theta$ os en dos usos retóricos que concuerdan con el trazo que se dispone en el análisis de los discursos cimentados en un personaje como Alcibíades. En primer lugar, el filósofo apunta que el orador es meritorio de un mayor crédito ante los oyentes gracias a que los persuade por medio de su $\hat{\eta} \theta 0 \varsigma,{ }^{3}$ esto es, que el público está más dispuesto a dejarse guiar por las palabras de una persona digna de confianza. Pero este aspecto no queda en el mero juicio previo que se tiene del orador, sino que de dicho $\hat{\eta} \theta$ o se construye una manera específica de la $\pi i ́ \sigma \tau 1 \varsigma$, puesto que la $\check{~} \xi_{1} \varsigma$, el modo de ser, es análogo del modo de persuadir. ${ }^{4}$ De acuerdo con Vianello, "el $\hat{\eta} \theta$ os resulta ser, pues, un óptimo medio para lograr la persuasión del auditorio, sobre todo en las circunstancias de un juicio legal o de una sesión pública", 5 o, como ocurre muchas veces, y es el caso de Alcibíades, en las cuestiones en las que lo judicial llega a mezclarse con lo político, y las fronteras de lo público y de lo privado se desvanecen.

La tradición retórica ha conservado cuatro discursos prácticamente íntegros sobre los asuntos políticos y familiares relacionados con Alcibíades: los discursos XIV y XV de Lisias, el XVI de Isócrates y el IV de Andócides, además de fragmentos de otras piezas oratorias, cuyos contenidos se corroboran o se refutan en las referencias que se hallan principalmente en Tucídides y en Jenofonte.

El discurso más antiguo que nos ocupa es el IV de Andócides, fechado hacia el 415, en ocasión de los sucesos en torno a la expedición a Sicilia y la intervención de Alcibíades en estos asuntos. El contexto, ficticio con seguridad, de esta pieza ora-

\footnotetext{
${ }^{3}$ Arist., Rhet., 1356a 5 y ss.

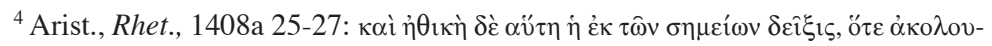

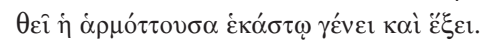

5 Paola Vianello, "El î̀ $\theta$ o del orador: Aristóteles, Dionisio de Halicarnaso y Lisias", Noua tellus, 25-1, 2007, p. 25.
} 
toria es la Asamblea en la que Nicias, Alcibíades y Féax, orador de este discurso, tienen que defenderse para evitar el ostracismo. Así como los discursos XIV y XV de Lisias han sido considerados espurios, ${ }^{6}$ se piensa que el de Andócides también es ficticio, escrito como propaganda política, ${ }^{7}$ y se cree que fue escrito para atacar el programa político de Alcibíades y su hetería, ${ }^{8}$ atribuyéndole la profanación de los misterios de acuerdo con diversas declaraciones que éste mismo orador menciona en su discurso II, Acerca de los misterios. Llama la atención el hecho de que, precisamente antes de los acontecimientos señalados, Alcibíades se haya visto envuelto en un juicio de ostracismo en donde se le juzgaba junto con Nicias e Hipérbolo (c. 418/417). El destierro de este último fue posible gracias a la alianza entre los grupos de Alcibíades y de Nicias, y quizá con ello estos dos políticos lograron que

\footnotetext{
${ }^{6}$ Harpocración consideró espurio el discurso XIV de Lisias, mientras que el XV ni siquiera lo menciona. K. Münscher, $R$. E., X col. 2161-2163, señala que estos discursos y el XVI de Isócrates son panfletos políticos en favor y en contra de Alcibíades respectivamente. F. W. Blass, Die attische Beredsamkeit, I, Leipzig, B. G. Teubner, pp. 486 y ss., indica que XIV y XV sí son de un mismo autor, aunque no necesariamente de Lisias. A favor de la paternidad lisiaca de estos discursos se ha manifestado C. Carey en Lysias, Selected Speeches, Cambridge, Cambridge University Press, 1989.

7 Cf. A. E. Rautbistchek, "The Case against Alcibíades (Andocides IV)", TAPhA, 79, 1948, pp. 191-210; Gerardo Ramírez Vidal, "Introducción”, en Andócides, Discursos, México, UNAM, 1996, pp. XXXII-XXXIII.

${ }^{8}$ Alcibíades era un Alcmeónida, quizá la familia más influyente en la esfera política y social en la segunda mitad del s. v. Fue hijo de Clinias y de Dinómaxes, primo de Pericles bajo cuya tutela se educó. La familia afirmaba que sus orígenes se remontaban hasta Néstor, el rey pilio que participó en la guerra de Troya. Isóc., XVI 25-26, utiliza el linaje noble de Alcibíades para argumentar a su favor en labios de su hijo, cf. Paus. 2.18.9; J. K. Davies, Athenian Propertied Families 600-300 B. C., Oxford, Clarendon Press, 1971, pp. 254, 259-260. De acuerdo con Ch. Pecorella Longo, Eterie e gruppi politici nell'Atene del IV sec. a. C., Firenze, Olschki, 1971, p. 7, n. 1: "Nel corso del v secolo per eterie si intende l'associazione di un certo numero di individui, molto spesso coetanei e appartenenti alla medesima classe sociale [...] legati da ideologie e interessi comuni i quali si riuniscono per il conseguimento di uno o piú scopi per lo piú di carattere politico, sociale, giudiziario".
} 
fueran elegidos estrategos en el 417. ${ }^{9}$ No es raro que Andócides retomara el asunto como motivo de su peroración para atacar el programa de la hetería de la que formaba parte el estratega.

A grandes rasgos, Andócides describe la personalidad de Alcibíades refutando lo que éste cree que ha hecho en beneficio de la ciudad; en una segunda parte, mezcla los rasgos particulares de su vida privada con los de su vida pública con el único fin de castigar a los más insolentes de la ciudad para hacer respetar las leyes. ${ }^{10}$ La comparación entre Féax y Alcibíades llevaría a los jueces a una comparación falaz, ${ }^{11}$ pues el orador de este discurso no defiende su caso, sino que expone pormenores de la vida pública y privada de Alcibíades. ${ }^{12}$ Esto es prueba, además, del carácter panfletístico de And., IV.

En efecto, en el discurso IV de Andócides no hay una acusación clara y contundente contra Alcibíades. Se trata de una serie de argumentos que objetan las acciones de este líder para desacreditarlo públicamente, porque el discurso está dirigido, se supone, a la Asamblea y, así, lograr su ostracismo. ${ }^{13}$ Lo que en sí defiende Andócides es la propaganda oligárquica, de la cual formaba parte como descendiente de la aristocracia. Así, por ejemplo, es elocuente el hecho de que critica negativamente una ley adoptada por la democracia relativa al

\footnotetext{
${ }^{9} \mathrm{~F}$. Sartori, Le eterie nella vita politica ateniese del IV e V secolo a. C., Roma, L'Erma di Bretschneider, 1967, pp. 79-80. "Ma v'è in questa lotta, a mio avviso, un aspetto nuovo: piú che uno scontro di eteria essa si può considerare un accordo delle eterie moderate di Nicia e del suo sostenitore Feace con quella di Alcibiade, fino a quel momento loro avversario ai danni di Iperbolo e della sua fazione".

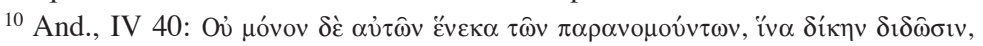

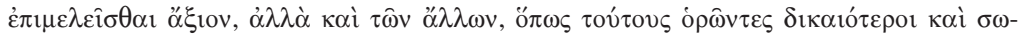

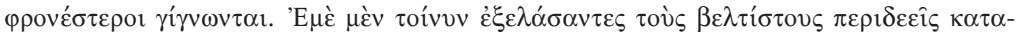

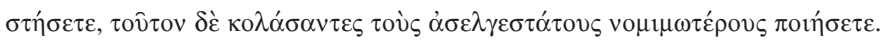

${ }^{11}$ Acerca de este modo de argumentar, cf. Gerald Hauser, "The Example in the Aristotle's Rhetoric: Bifurcation or Contradiction?", Philosophy and Rhetoric 1, 1968, pp. 78-90.

${ }^{12}$ And., IV 10.

${ }^{13}$ And., IV 25-34.
} 
ostracismo, ${ }^{14}$ porque contradice el juramento de la Asamblea $\mathrm{y}$ del Consejo, que no permite condenar a nadie sin juicio, y discurre una serie de razones para justificar su oposición a esta ley. El modo de cerrar esta defensa es magistral y precisa para sus fines, porque equipara a la democracia y a la oligarquía en el punto de la justicia: "Sin embargo, se considera que las mejores decisiones son aquellas que mejor se adaptan a democracias y oligarquías y que tienen el mayor número de partidarios". ${ }^{15}$

Por lo demás, Féax (Andócides) afirma que ha sido incoado a causa de su odio manifiesto contra la democracia, circunstancia que rechaza. ${ }^{16}$ Sea cierto o no este hecho, el caso es que el orador no puede ocultar su pro-oligarquismo, pues, por una parte, expresa la admiración que siente por Arístides, ${ }^{17}$ Milciades y Cimón, ${ }^{18}$ que eran nobles como él, a quienes compara con Alcibíades de modo negativo; y, por otro lado, su proespartanismo es evidente en torno a este líder, cuando sostiene que "él es tan diferente de los lacedemonios que mientras ellos aceptan sus derrotas, incluso con sus aliados cuando compiten en su contra, éste ni con sus conciudadanos, sino que abiertamente ha declarado que no va a permitirlo a ninguno de los que deseen rivalizar con él". ${ }^{19}$

\footnotetext{
${ }^{14}$ And., IV 3.

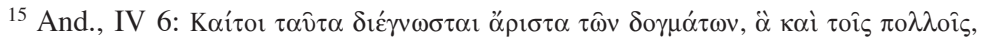

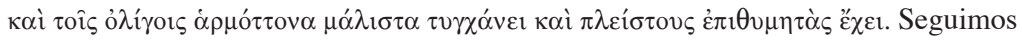
la traducción de Gerardo Ramírez Vidal: Andócides, Discursos, México, UNAM, 1996.

${ }^{16}$ And., IV 9

${ }^{17}$ And., IV 11-12.

${ }^{18}$ And., IV 33.

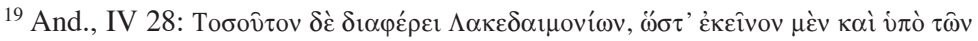

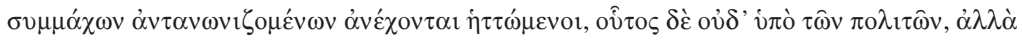

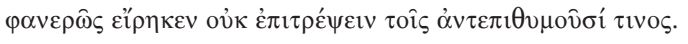

Cf. Mariateresa Galaz Juárez, “Oratoria y Derecho”, en Paola Vianello, Oratoria griega, México, Facultad de Filosofía y Letras, UNAM, 1986, pp. 49-56, quien estudia la tergiversación de las leyes en la argumentación a partir de los compo-
} 
La intención del discurso Contra Alcibíades era la de azuzar a la audiencia democrática, a quien dirige sus argumentos: "Pero lo más asombroso de todo es que, aunque se trata de una persona de tal calaña ( $s c$. Alcibíades), dice sus discursos como si fuera partidario de la democracia; él tacha a otros de oligarcas y de enemigos del pueblo"; ${ }^{20}$ y al mismo tiempo trata de enemistar a los oligarcas contra Alcibíades: el caso con Diomedes en relación con la competencia ecuestre en Olimpia, tiene como finalidad demostrar que Alcibíades, al arrebatar indebidamente el triunfo a aquél, desprecia una actividad propia de los oligarcas y la deshonra; se trata, en suma, de dejar a este personaje en malos términos con ambos grupos políticos, ${ }^{21}$ persiguiendo de este modo que no tuviera absolutamente ningún apoyo para sus fines militares y políticos.

La doble estrategia retórica dispuesta por Andócides para desacreditar a Alcibíades obedece al hecho de que, en el fondo, existe un pugna entre las heterías, cuyos medios para obtener el poder y la forma para llevar a cabo sus propuestas políticas y militares diferían entre sí: Alcibíades era partidario de un régimen oligárquico más ambicioso, pues pretendía expandir los dominios de Atenas en otros lugares como Sicilia y establecer relaciones que subordinaran a otras poleis, proyecto al que se oponía Nicias; ${ }^{22}$ en consecuencia, hay que situar a Andócides en esta misma línea ideológica: la oposición a las decisiones de la Asamblea en torno a los sucesos políticos del 415 para boicotear la expedición a Sicilia, para lo cual no dudó, junto con otros ciudadanos, en participar en la mutilación de los Hermes, no obstante que esta deidad era tutelar de su clan, razón por la cual su vida quedó marcada para siem-

nentes verosímiles. En el caso que nos ocupa, no importa tanto la ley, sino el hecho de dejar una pésima impresión del $\hat{\eta} \theta$ os del adversario político.

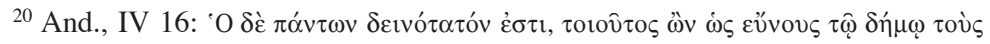

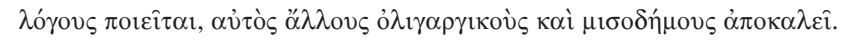

${ }^{21}$ And., IV 25 y ss.

${ }^{22}$ Cf. Tuc., VI 13, 1; 25, 1. 
pre, al punto de que en el año 400 tuvo que defenderse de las acusaciones del grupo de Terámenes acerca de la profanación de los misterios. ${ }^{23}$ De cualquier modo, tanto Féax (Andócides) como Alcibíades eran identificados como enemigos de la democracia, pero el primero rechaza las acusaciones de ser adverso y subversivo a este sistema y sistemáticamente acusa al segundo por ese flanco. ${ }^{24}$

Por otra parte, en el plano de la construcción retórica se encuentra un paralelismo en la introducción al ataque de And., IV 10, el de la defensa de Isoc., XVI 3 y de Lys., XIV 2. ${ }^{25}$ En los tres casos se alude a los actos de Alcibíades para desautorizarlo - Andócides y Lisias - y para defenderlo - Isócrates-. Andócides hace decir al orador de su discurso que, aunque él es uno de los acusados, dejará su caso a un lado y hablará de la vida de Alcibíades, lo que en cierto modo confirmaría el carácter panfletístico de la peroración, pues la ley prohibía salirse del asunto y en este caso el hecho es enunciado con tal evidencia que no puede ser inadvertido para el supuesto tribunal. ${ }^{26}$ En efecto, si lo que se busca es la salvación del ostracismo, Féax utiliza la argumentación contra Alcibíades para escapar de tal situación. El tono que Lisias maneja es semejante al de Andócides:

And., IV 10: "Estoy indeciso, sin embargo, por dónde empezar, debido a que son múltiples sus faltas y resulta un obstáculo

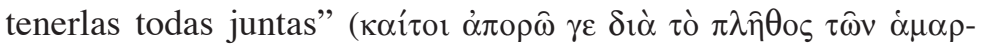

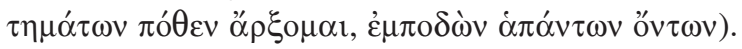

Lys., XIV 2: "No son pequeños sus delitos ni merecen perdón ni ofrecen esperanza de que será mejor de ahora en adelante"

\footnotetext{
${ }^{23}$ El hijo de Alcibíades intenta demostrar que su padre nada tuvo que ver en la profanación de los misterios, según se desprende de Isoc., XVI 6-8.

${ }^{24}$ And., IV 8 y 13 ss.

${ }^{25}$ Los discursos referidos de Isócrates y de Lisias fueron compuestos cuando Alcibíades, el estratego, ya había muerto. Lys. XIV y XV están fechados 395-396. Blass, op. cit., II, pp. 204 y ss., fija en 397 el XVI de Isócrates.

${ }^{26}$ Cf. Arist., Rhet., 1354a 21-25.
} 


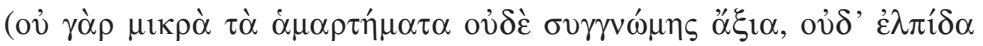

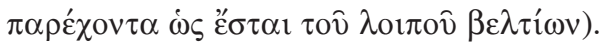

Y para ambos oradores Alcibíades es un delincuente público:

And., IV 10: "Pero sí voy a mostrar los actos que ha realizado contra la ciudad, contra sus familiares y contra los demás ciuda-

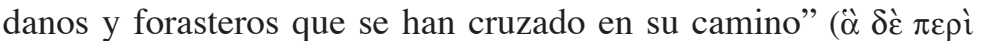

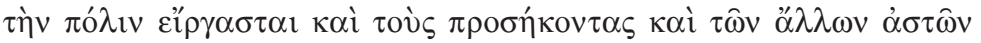

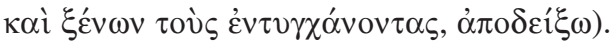

Lis., XIV 1: "En el caso de que alguien no haya sido agraviado por él en particular, no es menos pertinente, en razón de sus

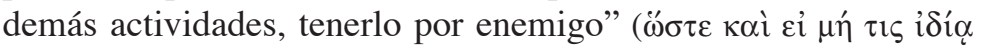

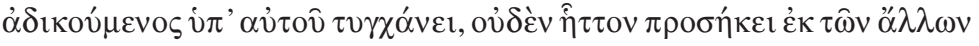

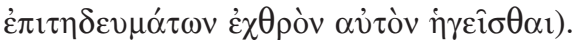

La respuesta que se encuentra en Isócrates en contra de la acusación de que Alcibíades es un enemigo público consiste en mencionar los beneficios que hizo para la ciudad y que todo lo que se afirma de él son meras calumnias, en donde se mezcla lo privado con lo público. ${ }^{27}$ Sin duda una táctica esencial para la desacreditación pública es manchar la reputación del enemigo, ${ }^{28}$ y por ello es un topos acertado el de dibujar un carácter contrario a la opinión general del pueblo. No obstante, ante las muchas acusaciones en contra suya y de su padre, Alcibíades reprueba dicha estrategia (XVI 4) e, incluso, argumenta que quienes lo acusan son insolentes por "utilizar tal libertad de palabras sobre un muerto" (XVI 22), en obvia

\footnotetext{
${ }^{27}$ Isoc., XVI 2-3. El discurso XVI de Isócrates fue compuesto para que el hijo del estratego se defendiera de la acusación de Tisias, en nombre de Diomedes, quien acusó a Alcibíades, el padre, de haberse apoderado de los troncos de caballos en la Olimpiada del 416. La defensa de Isócrates debe considerarse una respuesta a And., IV 26-33, en donde Féax expone los pormenores del modo en que Alcibíades ultrajó a Diomedes. Cf. Plut., Alc., 12 3; Blass, op. cit., II, p. 205.

${ }^{28}$ Cf. G. M. Calhoun, Athenian Clubs in Politics and Litigation, Roma, L'Erma di Bretschneider, 1964, pp. 56-57.
} 
referencia al célebre estratego. Por ello, al enmarcarse en la época de la democracia, los discursos mencionados aluden al carácter general del pueblo que había en ese momento, sobre todo teniendo en cuenta que los discursos de Isócrates y de Lisias referidos habrían tenido su efecto político en el contexto de la restauración de la democracia, luego del periodo de los Treinta Tiranos.

En oposición a lo sostenido por Isócrates, en Lys., XIV 9, se argumenta el $\hat{\eta} \theta$ os pernicioso para la ciudad del hijo de Alcibíades. El punto central es dejar entrever cómo es que este Alcibíades desprecia a la ciudad y a sus leyes, lo que apunta a cierta definición de su $\hat{\eta} \theta$ os, un carácter que le viene de familia, según quiere dejar sentado Lisias. En primer término se desarrollan cuatro premisas que tienen la misma conclusión: a) Alcibíades ha llegado a tal grado de maldad, b) desprecia a la ciudad y teme a los enemigos, c) tanto ha deseado servir como caballero, d) tan poco interés ha sentido por las leyes, que, en conclusión, no le preocupa ser enjuiciado por diversos

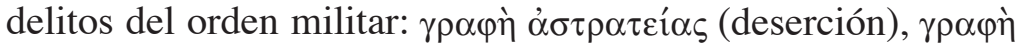

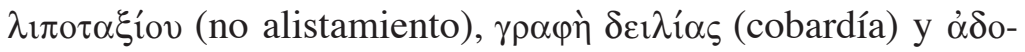

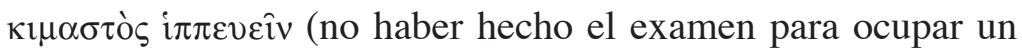
puesto en la caballería). ${ }^{29}$

Hay que observar, además, que la disposición antitética de las premisas independientes resalta el contenido de las ideas contrarias al espíritu que pretende mostrar la parte acusadora. En la segunda parte de Lis., XIV 9, se expresa cómo Alcibíades, siendo consciente de sus delitos, por cobarde prefirió: a) perder todos sus bienes que serían confiscados por el pueblo,

\footnotetext{
${ }^{29}$ Según se desprende de Lys., XIV (específicamente parágrafo 7) y XV. Para cualquiera de estos delitos, las penas eran muy severas, pues iban desde la pérdida de los derechos ciudadanos, hasta un probable juicio sumario llevado a cabo por los estrategos. Cf. A. R. W. Harrison, The Law of Athens. Procedure, Oxford, Clarendon Press, 1971, pp. 169 y ss., U. E. Paoli, Studi di diritto attico, Firenze, s. e., 1930, pp. 304 y ss., Mac Dowell, The Law in Classical Athens, London, Thames and Hudson, 1978, p. 160.
} 
b) quedar incurso en el proceso que se le sigue, antes que estar entre los ciudadanos y servir como hoplita. Entonces, de acuerdo con lo descrito, se desprende que Alcibíades estaba consciente de lo que hacía ${ }^{30}$ y prefirió enfrentarse a otros problemas de tipo social y judicial, antes que ir al frente del ejército entre los hoplitas. De allí que sea acusado de $\delta \varepsilon \imath \lambda i ́ \alpha$ (cobardía).

Para Lisias, los actos de Alcibíades son muestra de su carácter oligárquico y totalmente opuesto al bien de la ciudad, lo mismo que para Andócides; pero los discursos XIV y XV tienen por objeto persuadir a un público democrático, como lo demuestra la comparación entre la guerra emprendida por los exiliados del 404 para recobrar a Atenas de manos de la oligarquía y las ocasiones en que Alcibíades peleó al lado de los lacedemonios en contra de su propia patria. ${ }^{31}$ Así, es claro que Lisias reconoce en un solo grupo a los oligarcas y no distingue, retóricamente, las diversas asociaciones entre sí, pues el mismo Alcibíades fue enemigo de la extrema oligarquía.

Con cuadros como los dibujados por Lisias y por Andócides, es difícil creer en el carácter del estratega expuesto por Isócrates. ${ }^{32}$ El hijo de Alcibíades navega contra la corriente y presenta a su padre como partidario de la democracia: no participó en el régimen de los Cuatrocientos, a pesar de haber sido invitado, ${ }^{33}$ lo cual no es nada extraño, pues entre los principales líderes de la revuelta oligárquica se hallaban Antifonte y Critias, dos enemigos declarados de Alcibíades, por lo que esta prueba no descalifica a Alcibíades como pro-oligarca y sí, en cambio, confirma la enemistad entre los miembros de las distintas heterías.

En lo que se refiere a la defección de las ciudades aliadas de Atenas, Isócrates no hace más que mencionar los datos que de manera contraria aparecen en otras fuentes. Baste un ejem-

\footnotetext{
${ }^{30}$ Sobre la voluntad de las acciones cf. Arist., Rhet., I 1368b 7 ss. y 1373 b 1 ss.

${ }^{31}$ Lys., XIV 32-33.

${ }^{32}$ Contrástese Isoc., XVI con Tuc., VI 27 3; 53 1; 601.

${ }^{33}$ Isoc., XVI 5.
} 
plo: en Isoc., XVI 15 se dice que Alcibíades logró que las ciudades más grandes del Peloponeso hicieran defección en contra de los lacedemonios, pero en Lys., XIV 30, se lee que Alcibíades fue el que convenció a los lacedemonios de que fortificaran Decelia y con ello se inició la defección de las islas en contra de Atenas, pues el fue quien

persuadió a los lacedemonios para fortificar Decelia y navegó a las islas para que se rebelaran y se hizo preceptor de los males de la ciudad, y con mayor frecuencia junto con los enemigos luchó contra la patria, más que junto con los ciudadanos en contra de aquéllos. Por ello conviene, tanto a ustedes como a los descendientes, tomar venganza en cualquiera que se apoderen de ellos. ${ }^{34}$

En Isoc., XVI 10-11, se mencionan estos mismos hechos, pero el orador se limita a señalar que se trata de calumnias y no demuestra por qué lo son. La propaganda política que se presenta en los discursos mencionados, describe la lucha constante entre oligarquía y democracia, y en ese juego Alcibíades parece oscilar de un matiz político a otro, en el marco de las heterías, con objeto de llevar a cabo sus aspiraciones políticas personales. El hecho de que sobre su persona se conserven más discursos que sobre cualquier otro político de su tiempo, es síntoma del grado de importancia que tenía para la política ateniense de la democracia.

El artilugio retórico consistente en ventilar asuntos de la vida privada era, ciertamente, otro de los flancos preferidos por los oradores para el descrédito político. De igual manera, los actos de la vida personal eran el sustento para que el orador mostrara tal o cual carácter ante el jurado, con el fin de

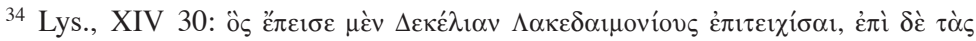

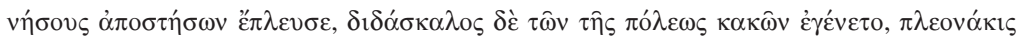

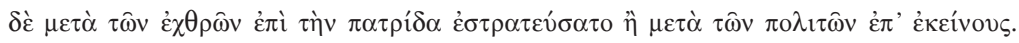

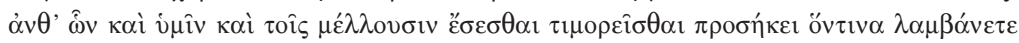

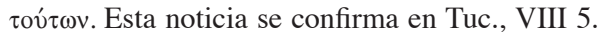


inducirlo a cierta disposición favorable o no. Los argumentos usados, en consecuencia, son de carácter ético y la mayoría de las veces nada tienen que ver con el asunto que se estaba tratando - como sucede con los cuatro discursos mencionados-, de modo que su utilidad era puramente difamatoria o de defensa, en el caso de Isoc., XVI.

En el discurso de Andócides son cuatro las acusaciones que se refieren a la vida privada de Alcibíades: el asunto en torno a su esposa, a la que no sólo ofendió al conducir a otras mujeres a su propia casa, sino que demostró que su casamiento era por interés monetario, ya que obtuvo una dote muy grande y, además, exigió el dinero que Hipónico le prometió cuando tuviera un niño. ${ }^{35} \mathrm{El}$ motivo del argumento señalado carecería de utilidad si no se le relacionara con la actividad política; en efecto, lo que el atacante busca imprimir en la mente de los oyentes es la imagen de un hombre que, si no tiene la menor consideración con su familia, menos la tendrá con la ciudad: "¿qué acto no se debe esperar de Alcibíades contra cualquier ciudadano?, pues todo hombre tiene más consideración de sus familiares que de los extraños". ${ }^{36}$

La misma estrategia retórica aparece en la argumentación de Lisias. El carácter que se dibuja del hijo de Alcibíades pretende demostrar que él es culpable de deserción del ejército y de no alistamiento, para explicar cómo fue que violó las leyes y así demostrar un delito más: la $\delta \varepsilon \imath \lambda i ́ \alpha$ (cobardía); en consecuencia debe considerársele como enemigo público. Dichas acusaciones se enmarcan en los preparativos de los atenienses para apoyar a Tebas en la guerra contra Corinto, ${ }^{37}$ acción que finalmente no se concretó porque los atenienses tuvieron problemas para formar las líneas de combate. El juicio incoado al

\footnotetext{
${ }^{35}$ And., IV 13-15.

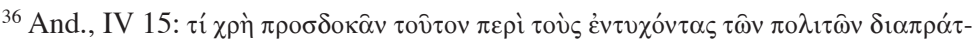

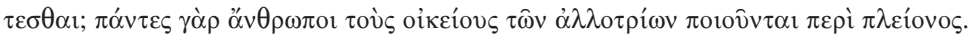

${ }^{37}$ Cf. M. Sordi, Propaganda e persuasione occulta nell'antichità, Milano, Pubblicazioni della Università Cattolica del Sacro Cuore, 1974, pp. 36 y ss.
} 
hijo de Alcibíades habría sido uno de procesos judiciales, con fuerte matiz político, que se iniciaron entonces en contra de aquellos que no respetaron las leyes de alistamiento y de asistencia al puesto de combate asignado. Además, se imprime la idea de que sus actos son el resultado de la tradición familiar e, incluso, Alcibíades fue superado por su hijo, ${ }^{38}$ una clara ironía mediante áuxesis. Uno de los puntos que desacreditan a Alcibíades es el tipo de relación filial que guardaba con su padre:

Cuando aquél (sc. Teotimo) se apoderó del territorio ( $s c$. que era propiedad de Alcibíades padre), primero lo humilló en plena juventud (sc. a Alcibíades hijo) y, al final, lo encarceló y pedía dinero por él. Pero su padre le odiaba con tanta fuerza, que contestó que ni sus huesos recogería cuando muriera. Y cuando éste (sc. Alcibíades padre) murió, lo rescató Arquebíades, que era su amante. ${ }^{39}$

Es decir, Alcibíades no recibió los honores de la sepultura por parte de su vástago. La finalidad es, nuevamente, advertir que un ciudadano de tal naturaleza, que no se arrepiente de lo que ha hecho ni de lo que vaya a suceder a causa de sus actos, no puede ser más que culpable de lo que se le acusa, ${ }^{40}$ y en consecuencia se le marca políticamente. Por otro lado, frases como "su padre lo odiaba con tanta fuerza, que contestó que ni sus huesos recogería", indican la subjetividad con la que se aborda el asunto y la intención sesgada del orador al afirmar algo que no puede demostrar, que no pudo constatar y que, como prueba, sólo intenta impresionar a los oyentes. Este es, a mi juicio, un claro ejemplo de argumento usado en la panfle-

\footnotetext{
${ }^{38}$ Lys., XIV 26.

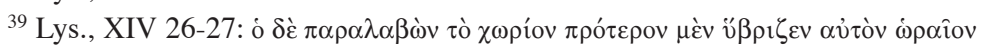

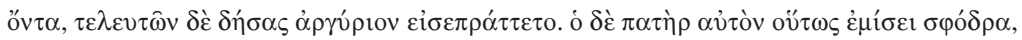

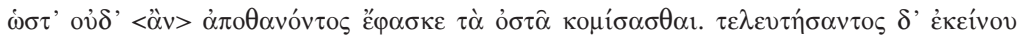

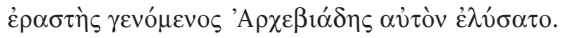

${ }^{40}$ Lys., XIV 29.
} 
tística. Para Aristóteles, el hijo de Alcibíades sería el ejemplo del $\hat{\eta} \theta$ os noble que se degenera, ${ }^{41}$ pero de los discursos de Lisias se conjetura que no sólo hay tal deformación, sino que en la lucha política y en los menesteres judiciales es válido cualquier indicio para construir argumentos destructores a partir del carácter del adversario.

En lo que se refiere a la defensa de Isócrates, no hay un solo mérito que califique a Alcibíades hijo como buen ciudadano, lo cual hace sospechar que, siendo una peroración de defensa, mucho de lo que afirma Lys. XIV y XV sea verdad. Por otra parte, las virtudes que enumera de su padre, al igual que ocurre con los hechos públicos, son desmentidos por Lisias y Andócides; incluso, algunos asuntos en los que coinciden la mayoría de los autores, como es el caso del matrimonio de Alcibíades padre y cómo llegó a mal término, son omitidos o mencionados superficialmente por Isócrates. ${ }^{42}$ En lo que este orador pone énfasis es en el origen noble de Alcibíades y en las relaciones que estableció con personajes destacados como Pericles, que fue su tutor, ${ }^{43}$ utilizando un recurso ad hominem para tratar de modificar la opinión del público.

A partir del ejemplo tomado en torno a la actividad política de Alcibíades, es claro que bajo el sistema democrático ateniense no se tenían prejuicios para dar a conocer la vida privada de los hombres políticos, si con ello se lograban sus fines particulares, tal como ocurre, con sus matices, en nuestros días. Los argumentos basados en la vida personal imprimían cierta imagen del acusado en el público, a partir de elementos aceptados como valores y reglas de convivencia, que al violentarse producían el rechazo del pueblo. La vida escandalosa de Alcibíades hijo descrita en Lys. XIV rompe con las reglas aceptadas por la comunidad, de modo que su

\footnotetext{
${ }^{41}$ Rhet., 1390b 14 y ss.

${ }^{42}$ Isoc., XVI 16-21.

${ }^{43}$ Isoc., XVI 25 y ss.
} 
vida privada lo desacredita para la vida pública. El objetivo de los discursos de Lisias, así como el de Andócides, fue, como se puede inferir, el de frenar las aspiraciones políticas de una facción oligárquica que intentaba llevar acabo un programa político distinto al propuesto por los oligarcas extremistas y que estaba diametralmente opuesto al régimen democrático. Alcibíades hijo es acusado no sólo porque se pretenda tomar venganza sobre su persona a causa de los actos cometidos por su padre, como se afirma en Isoc., XVI 1-2, sino por el peligro que potencialmente representaba para los intereses de la hetería que posiblemente tuvo que ver con la muerte de su padre. Al hablar del proceder democrático de su padre, ${ }^{44}$ Alcibíades hijo pretende construir un $\hat{\eta} \theta$ os que también le sea favorable a él dado el contexto adverso en el que se hallaría pronunciando el discurso.

Así pues, los discursos en torno a la actividad política de Alcibíades demuestran el procedimiento de la construcción del $\hat{\eta} \theta$ o $\varsigma$ como recurso retórico que busca la definición del personaje en cuestión, pues de esa manera se crea en los receptores una imagen que influye en el juicio político. Si, como afirma Aristóteles, ${ }^{45}$ el $\hat{\eta} \theta$ os es prácticamente la prueba principal del discurso y si tal carácter es presentado en concordancia con los valores reconocidos por los receptores, entonces es verosímil que, por medio de discursos como los de Andócides y Lisias, la caracterización pública y privada de Alcibíades sea un entramado argumentativo que pone de relieve las acciones pero no sus causas y sus fines. Por este camino, resulta siempre más complejo el análisis de las propuestas o de los intereses políticos que entran en juego en la lucha por

\footnotetext{
${ }^{44}$ Isoc., XVI 36-38. De hecho, lo que sigue (XVI 39-50) es una somera recapitulación de lo sucedido bajo la tiranía de los Treinta en la que Alcibíades, el estratego, fue desterrado "de toda Grecia" (40); teniendo esta aseveración como fundamento, el orador de este discurso pretende deslindar a su padre de cualquier ascendente con la oligarquía.

${ }^{45}$ Cf. Arist., Rhet., 1356a 13-14; 1378a 10.
} 
el poder. En cambio, es más efectivo determinar y fijar en el público el $\hat{\eta} \theta$ os del sujeto en cuestión, porque el análisis de recepción es inmediato y no necesita de mayor demostración. El discurso es de carácter pragmático, pues persigue la persuasión del oyente; tal acción está determinada por el fin dispuesto, de tal modo que el receptor es capaz de emitir un juicio sobre el carácter del emisor movido por las palabras de éste sin necesidad de reflexionar en el fondo. ${ }^{46} \mathrm{Al}$ estar determinados los puntos de contacto entre emisor y receptor, se entabla entre ellos una argumentación determinada por el $\hat{\eta} \theta 0 \varsigma$ y las acciones del orador; prueba de este mecanismo es el estudio minucioso de tal proceder en la Ética Nicomaquea de Aristóteles (III, 4-6). Como la construcción de los argumentos que siguen la ruta del $\hat{\eta} \theta$ os parte de indicios generales, es la dinámica del discurso donde se cimienta, se desarrolla y se argumenta el carácter del sujeto del discurso ${ }^{47}$ Esto último es lo que sigue en muchos puntos, el ahora llamado marketing político, con sus grandes diferencias guardadas en favor de los logógrafos atenienses.

\footnotetext{
${ }^{46}$ Cf. Arist., Rhet., 1404a 7-8.

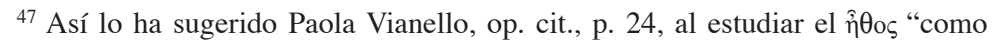
resultado del montaje "cinético" o "cinematográfico" de momentos sucesivos de pensamientos o actos descritos o expuestos en el discurso". Cf. Arist., De animo, 404b 8-28; 406a 17 y ss.
} 